\title{
Realizing low life cycle energy use and GHG emissions in coal based polygeneration with $\mathrm{CO}_{2}$ capture
}

\author{
Sheng $\mathrm{Li}^{1,{ }^{*}}$, Lin Gao ${ }^{1}$, Hongguang $\mathrm{Jin}^{1}$ \\ 1. Institute of Engineering Thermophysics, Chinese Academy of Sciences, P. O. BOX. 2706, Beijing, 100190 \\ * Corresponding author: lisheng@iet.cn
}

\begin{abstract}
Cogeneration of synthetic natural gas (SNG) and power from coal can realize both high energy conversion efficiency and low energy penalty for $\mathrm{CO}_{2}$ capture (CC). Life cycle energy use and GHG emission assessments are applied to coal based SNG and power cogeneration with $\mathrm{CO}_{2}$ capture. Four typical pathways are considered based on the main applications of SNG in China. Results show that when SNG is produced in a single product plant with $\mathrm{CO}_{2}$ capture and SNG is used for power generation, its life cycle energy use is averagely around 5\% lower than that of supercritical coal power with CC and even can be comparable with ultra supercritical (USC) with CC pathway. Such low energy use is mainly due to much lower energy penalty for $\mathrm{CO}_{2}$ capture in a SNG production plant than in a post-combustion coal fired power plant. The life cycle energy use of cogeneration plant with CC is $10 \%-19 \%$ lower than that of USC with $\mathrm{CC}$ due to system integration, the obvious higher $\mathrm{CO}_{2}$ concentration before separation and the consequent much lower energy penalties for $\mathrm{CO}_{2}$ capture. The life cycle GHG emissions of cogeneration with $\mathrm{CC}$ range from 135 to $150 \mathrm{gCO}_{2}$ eq./MJ, which are obviously lower than those of all coal power pathways including USC units (10\%-17\% lower than USC with CC). For steam and power cogeneration and pure vehicle operation pathways, the cogeneration technology with $\mathrm{CO}_{2}$ capture also shows obvious life cycle energy use and GHG emission advantages over its competitive pathways.
\end{abstract}

Keywords: SNG, cogeneration/polygeneration, $\mathrm{CO}_{2}$ capture, life cycle, $\mathrm{GHG}$ emissions, energy use

\section{Introduction}

Production of synthetic natural gas (SNG) from coal or biomass is thought to be an efficient way for coal and biomass utilization compared to coal to other alternative fuels such as methanol, DME etc. [1-4]. Coal to SNG can enforce the energy security considering both oil dependency and gas dependency in China are increasing quickly in these years [5]. However, the production of SNG from a traditional single product plant is thought to be not competitive to coal power pathways in terms of life cycle energy use and GHG emissions if no $\mathrm{CO}_{2}$ capture is applied [6-8]. Previous work claimed that the life cycle energy and GHG emissions of coal to SNG (in a traditional single product plant) were both normally higher than advanced coal power pathways [6-8]. It was reported that the life cycle GHG emissions associated with converting coal to SNG were averagely 1.35-1.60 times those associated with the coal to power pathway [6]. And under best conditions, the plant efficiency of traditional coal to SNG plant can be around 60\% [6], and the lower limits of its life cycle energy use and GHG emissions were reported to be comparable to the average levels of coal power pathway but still higher than ultra supercritical (USC) coal power pathway [9].

The high life cycle energy use and GHG emissions of SNG production in a traditional single product plant is mainly due to the high energy consumption for SNG production [9]. However, it was reported that cogeneration of SNG and power was more energy efficient [10-12]. In our previous work [9], the life cycle energy use and GHG emissions have been presented for SNG and power cogeneration technology and cogeneration shew comparable or better energy and environmental performances over other coal based alternatives. Nevertheless, the previous work did not consider the life cycle energy use and GHG emissions for SNG and power cogeneration technology with $\mathrm{CO}_{2}$ capture (CC). It was stated that the cogeneration plant can capture $\mathrm{CO}_{2}$ with quite low 
energy penalty compared to post-combustion coal fired power plants and may be the future directions toward high efficient, clean and decarbonization of coal utilization [13]. Technical and economic performances of the cogeneration technology with $\mathrm{CO}_{2}$ capture have been evaluated in these works [12-13]. The pathway of polygeneration with $\mathrm{CO}_{2}$ capture represent one of the most important future directions for clean coal utilization since China's energy structure is highly coal dependent and the emission reduction pressure is huge. However, it is important and necessary to evaluate the innovative PG with CC technology from life cycle viewpoint. Thus, this work aims to assess its life cycle energy use and GHG emissions, and the main outcomes may help policy makers to decide the choice of promising technologies for clean coal utilization.

\section{Coal based cogeneration/polygeneration with low energy penalty for $\mathrm{CO}_{2}$ capture}

This section will introduce the proposed coal based cogeneration/polygeneration technology with $\mathrm{CO}_{2}$ capture and its competitive pathways.

\subsection{Traditional coal to SNG plant}

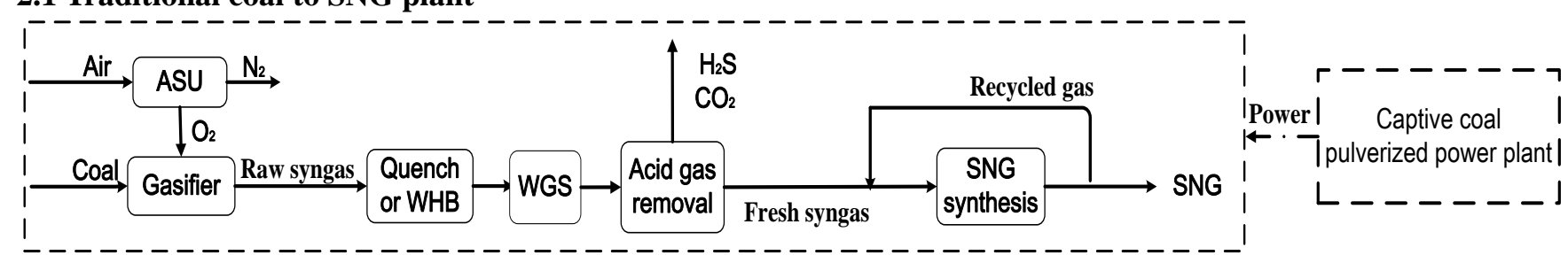

Figure 1 Traditional single SNG product plant

As shown in Figure 1, in traditional single SNG product plant, the raw syngas from a gasifier is cooled down to around $200 \sim 300^{\circ} \mathrm{C}$ through a quench or a waste heat boiler (WHB) unit. Then, the syngas is sent to water gas shift (WGS) unit to convert part of $\mathrm{CO}$ into $\mathrm{CO}_{2}$ and $\mathrm{H}_{2}$ by reacting with $\mathrm{H}_{2} \mathrm{O}$. Fresh syngas with $\mathrm{H}_{2} / \mathrm{CO}$ mole ratio around 3.0 is prepared to satisfy the stoichiometric requirement of the methanation reaction $\left(\mathrm{CO}+3 \mathrm{H}_{2} \rightarrow\right.$ $\mathrm{CH}_{4}+\mathrm{H}_{2} \mathrm{O}$ ). Acid gases (sulfur and $\mathrm{CO}_{2}$ ) need to be removed before the fresh syngas is sent to synthesis unit to avoid the effectiveness of the catalyst [13]. Fresh syngas will synthesize SNG in sequential reactors to produce the satisfactory product.

From the perspective of energy utilization, there are three main problems of single SNG product plant. One is that typically a small pulverized plant is needed to supply the power of the whole plant. And the efficiency of such kind of small pulverized plant is very low due to low steam parameters, limiting further improvement in the efficiency of the single product plant. Another energy utilization problem is that large amount of unreacted gas should be recycled to the inlet of the SNG synthesis reactors to ensure complete conversion of $\mathrm{CO}$ and $\mathrm{H}_{2}$ into $\mathrm{CH}_{4}$, resulting huge power is consumed to recompress the recycle gas and sharp energy consumption increase in chemical synthesis [10,13]. Also, large amount of steam is required in WGS unit [10,13].

In terms of $\mathrm{CO}_{2}$ capture from a single SNG product plant, $\mathrm{CO}_{2}$ is captured in acid gas removal unit and it is just a byproduct of syngas composition adjustment [13]. The $\mathrm{CO}_{2}$ concentration before separation is limited by the extent of WGS reaction which is further controlled by the stoichiometric requirement of methanation reaction. Typically, $\mathrm{CO}_{2}$ mole concentration is only around 30\%-40\% in a traditional single SNG product plant, causing a relative high energy consumption for $\mathrm{CO}_{2}$ capture.

\subsection{SNG and power cogeneration with low energy penalty for $\mathrm{CO}_{2}$ capture}

Aiming at the main energy utilization and $\mathrm{CO}_{2}$ capture problems of traditional single SNG product plant, a SNG and power cogeneration process with $\mathrm{CO}_{2}$ capture was proposed by our previous work [13]. As can be seen in Figure 2 that, part of the unreacted gas from SNG synthesis unit is recycled to the inlet of the reactor, and the left is sent to a combined cycle unit to generate power. By such integration, large amount of power consumption for recycle gas recompression is avoided and high efficient power generation is realized in a combined cycle other than in a small coal pulverized plant [13]. And WGS unit is abolished as there is no need to convert all $\mathrm{CO}$ and $\mathrm{H}_{2}$ 
into $\mathrm{CH}_{4}$ in a cogeneration plant, and thus steam consumption for WGS is no more required [13]. Furthermore, the sensible heat of the raw syngas from gasifier together with the heat release from SNG synthesis reactions is recovered in WHBs where steam is generated for power generation. Especially, for $\mathrm{CO}_{2}$ capture, the $\mathrm{CO}_{2}$ removal unit is rearranged after SNG synthesis other than before synthesis in a traditional single SNG product plant. Through the SNG synthesis reaction, $\mathrm{CO}$ and $\mathrm{H}_{2}$ in the syngas are converted into $\mathrm{CH}_{4}$, and $\mathrm{CO}_{2}$ is left. Obviously, 1 mole $\mathrm{CO}$ and 3 mole $\mathrm{H}_{2}$ just yield 1 mole $\mathrm{CH}_{4}$, resulting less total moles of the raw product gas and the enhancement of $\mathrm{CO}_{2}$ concentration [13]. Therefore, in this cogeneration plant, $\mathrm{CO}_{2}$ concentration before separation can be enriched to around 55\% by eliminating WGS and properly controlling the amount of recycle gas, and low energy penalty for $\mathrm{CO}_{2}$ capture is expected [13]. It was investigated in our previous work [13] that the efficiency of the whole plant could be as high as $59.7 \%$ when the plant yields a 2.82 SNG to power output ratio (the lower heating value of SNG product to electricity product) and around 66\% carbon is captured. In addition to high efficiency, the cogeneration plant with $\mathrm{CC}$ also shows good economic feasibility. It was studied that compared to IGCC + CC and single SNG production plant, the total annual cost of the cogeneration plant could be $3.8 \%$ lower [12]. And the cogeneration plant could realize low cost $\mathrm{CO}_{2}$ capture (around 7.9\$/t), which is far below PC plant employing post-combustion $\mathrm{CO}_{2}$ capture [12].

The double benefits from both system integration and $\mathrm{CO}_{2}$ concentration enhancement can result in near zero energy penalty for $\mathrm{CO}_{2}$ capture when the reference plants without $\mathrm{CO}_{2}$ capture are traditional single SNG product plant and IGCC plant [13].

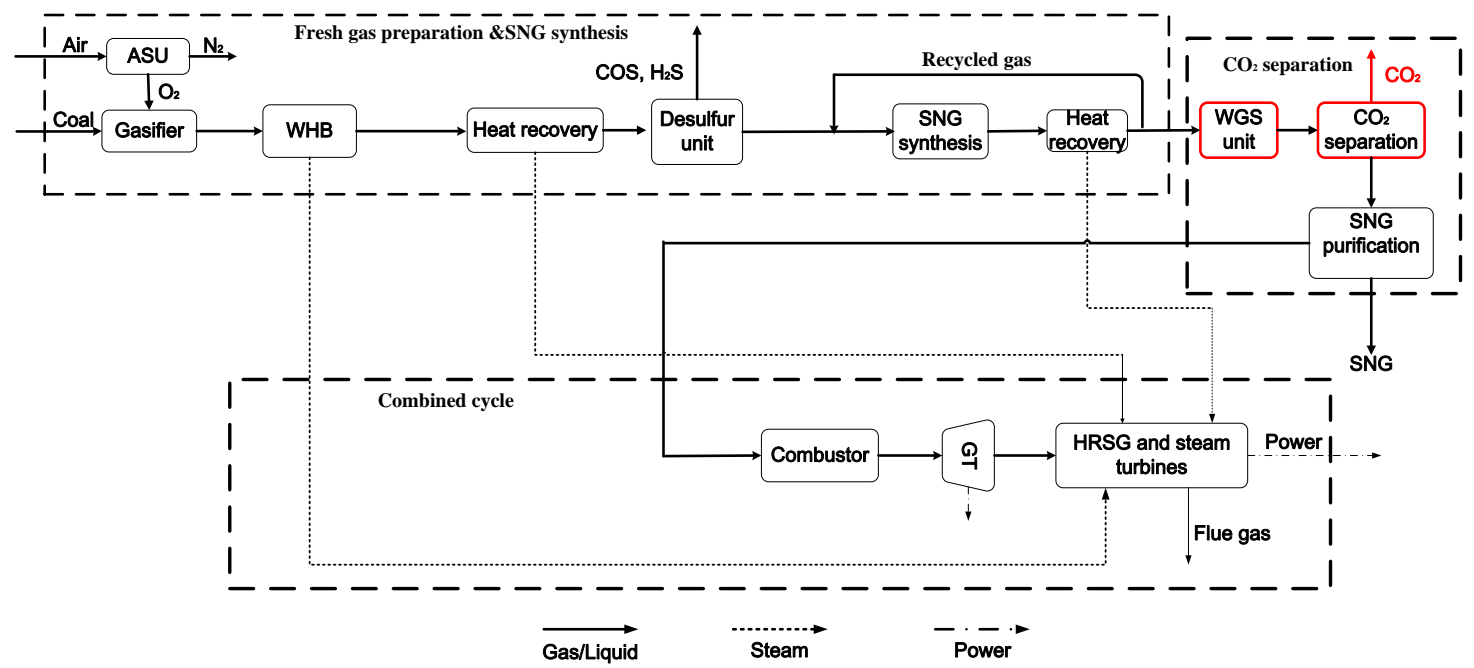

Figure 2 Coal based SNG and power cogeneration system with $\mathrm{CO}_{2}$ capture [13]

\section{Methodology}

3.1 SNG utilization and competitive alternative pathways

It was investigated that in China although natural gas (NG) applications are different from region to region, power generation, vehicle fuel, and heating in northern district of China are mostly included [7]. In this paper, four main pathways of the cogeneration technology with $\mathrm{CO}_{2}$ capture are considered based on the way of SNG/NG applications. (1) Power generation pathway. In this pathway, SNG produced from $\mathrm{PG}$ plant with $\mathrm{CO}_{2}$ capture is transmitted to a NGCC power plant located near end users for power generation. $\mathrm{CO}_{2}$ is captured from PG plant, and then is transported to a proper geological site for storage. The power generated from PG with CC plant is transmitted to end users. Two alternative pathways are considered, including traditional coal power and single SNG product with CC pathways. In coal power pathway, electricity produced from a post-combustion power plant with $\mathrm{CO}_{2}$ capture is transmitted through long distance to end users. And in traditional SNG production with $\mathrm{CC}$ pathway, $\mathrm{SNG}$ is produced from a single SNG product plant with $\mathrm{CO}_{2}$ capture and is transported to a NGCC plant 
for power generation. All $\mathrm{CO}_{2}$ captured from the plant is transported to a nearby site for storage. (2) Combined steam and power cogeneration pathway (PG with CC-steam-power). SNG is used to produce steam in NG fired boilers, and power from PG plant will be sent to end users. (3) Combined vehicle operation and power cogeneration pathway (PG with CC-SNGV). SNG is used to drive passenger car directly, and power for PG with CC plant is transmitted to end users. (4) Pure vehicle operation pathway (PG with CC-BEV). This pathway is similar with power generation pathway. The difference between the two pathways is the addition of electricity charging and vehicle operation. The life cycle scopes of coal based SNG and power cogeneration with $\mathrm{CO}_{2}$ capture pathways and their competitive alternatives are represented as dash lines in Figure 3.

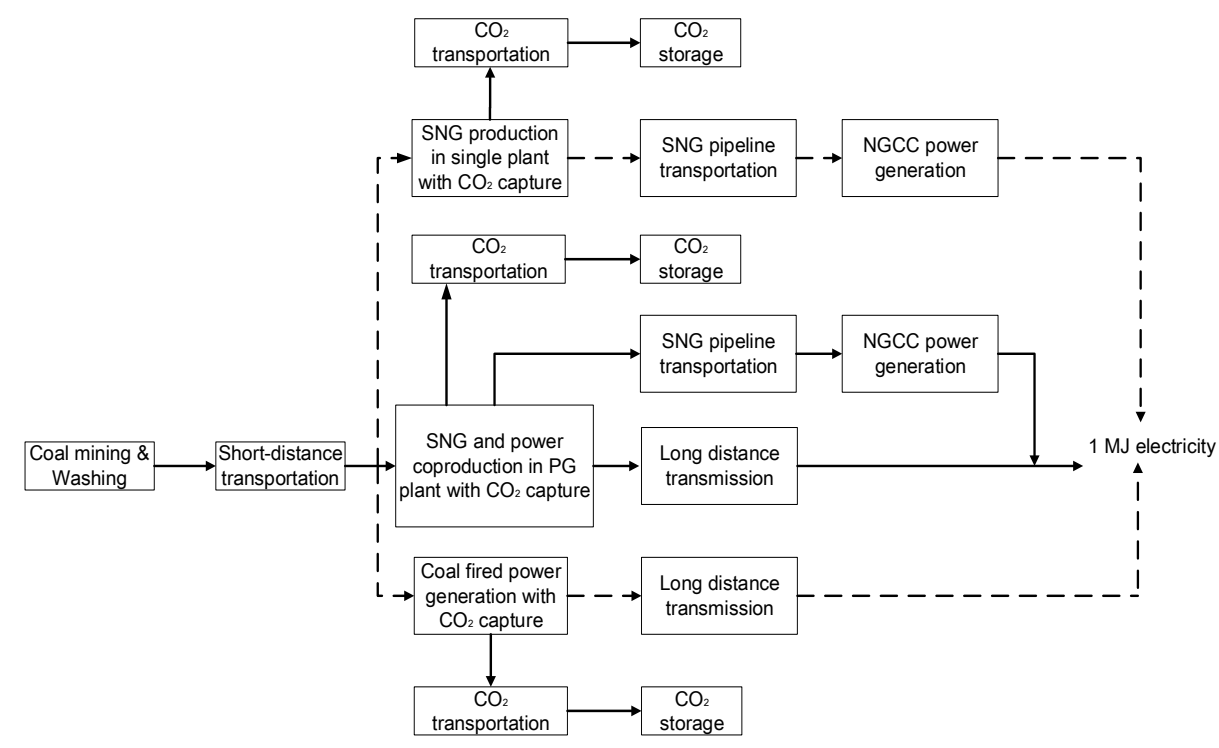

(a) Power generation pathway

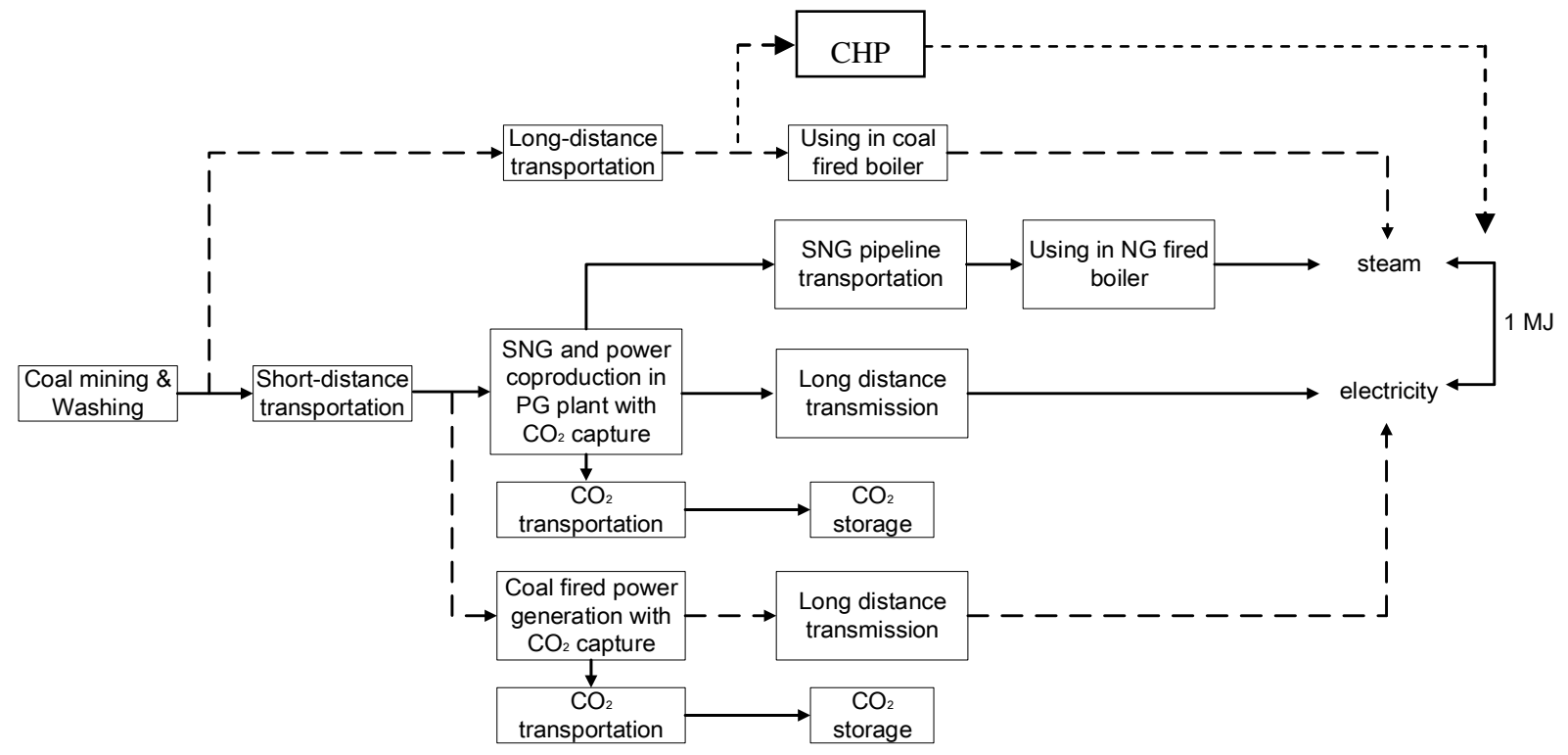

(b) Combined steam and power cogeneration pathway 


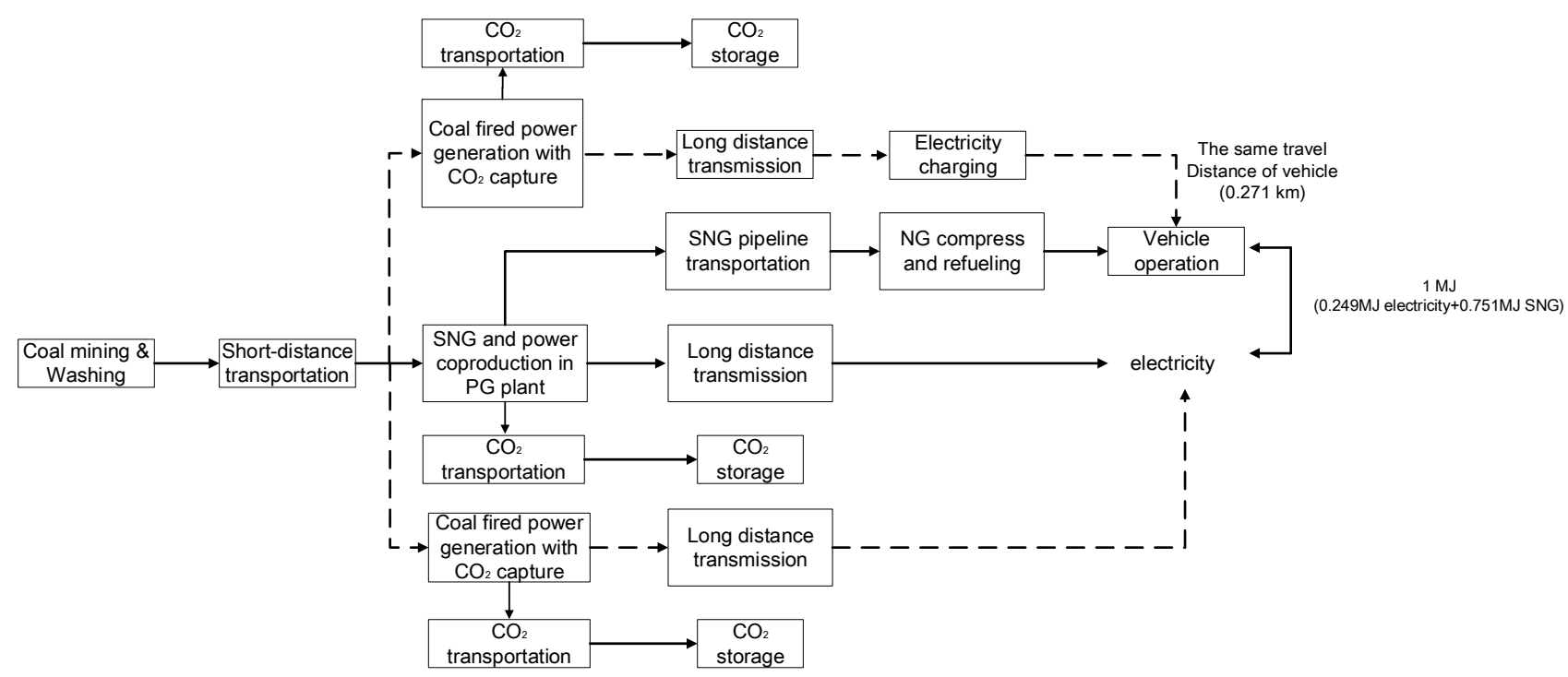

(c) Combined vehicle operation and power cogeneration pathway

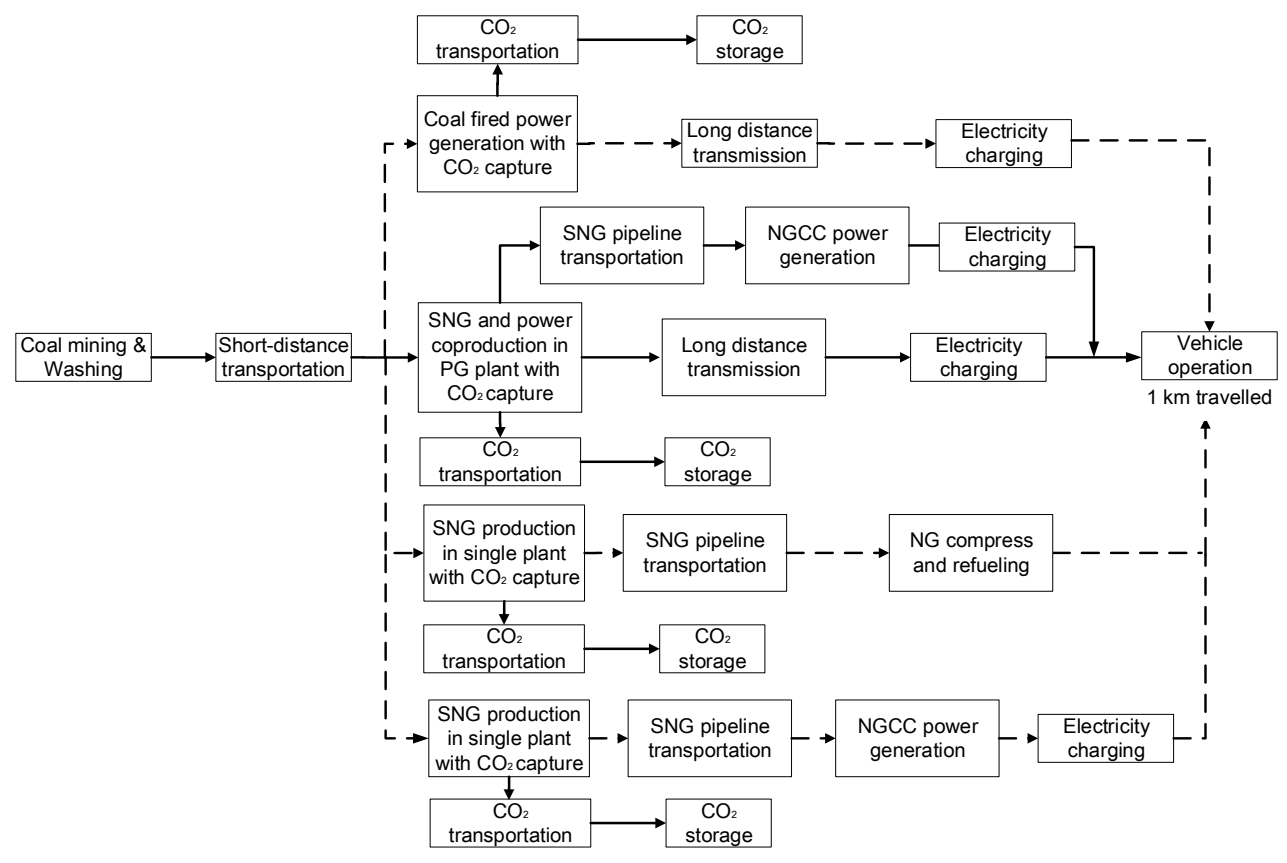

(d) Pure vehicle operation pathway

Figure 3 Scope definitions of coal based SNG and power cogeneration with $\mathrm{CO}_{2}$ capture and alternative pathways

3.2 Life cycle energy use and GHG emission calculation method

The method for calculating life cycle energy use is rewritten into Eq. (1) based on that in our previous work [9].

life cycle energy use $=\sum_{j=1}^{k} \sum_{i=1}^{n} E_{i, j}+E_{\text {end-output }}$

where $E_{i, j}$ is the consumption of $i_{t h}$ type energy in the $j_{t h}$ sub process, and $E_{\text {end-output }}$ is the final energy output provided to end users. And the total energy consumption is calculated using Eq. (2).

total energy consumption $=\sum_{j=1}^{k} \sum_{i=1}^{n} E_{i, j}$

Accordingly, GHG emissions related to energy use are counted in Eq. (3). Two types of GHG emissions, those caused by fuel combustion and fugitives during fuel production $\&$ transportation, are considered according 
to IPPC report [11].

life cycle GHG emissions $=\sum_{j=1}^{k-1} \sum_{i=1}^{n} \sum_{m=1}^{3} G W P_{m} * E_{i, j} * E F_{i, j, m}+\sum_{j=1}^{k} F E F_{m, j}+E M_{C C} \quad$ Eq. (3)

where $E F_{i, j, m}$ is the $m_{t h}$ greenhouse gas emission factor related to $i_{t h}$ type energy consumption during the $j_{t h}$ sub process excluding $\mathrm{CO}_{2}$ capture process, $F E F_{m, j}$ is the fugitive emission factor of $m_{t h}$ greenhouse gas, and $E M_{c c}$ refers to the emissions from $\mathrm{CO}_{2}$ capture plant.

$\mathrm{CO}_{2}, \mathrm{CH}_{4}$ and $\mathrm{N}_{2} \mathrm{O}$ are considered as the three main greenhouse gases, and the GWP value is 298 for $\mathrm{N}_{2} \mathrm{O}, 34$ for methane based on IPCC report [15]. It is worth to be noted the analysis scopes were limited to fuel cycle, and energy use and GHG emissions from equipment manufacturing and infrastructure construction are not considered.

\section{Basic data input}

\subsection{Technical performances of $\mathrm{CO}_{2}$ capture plant}

It was presented in our previous paper that the net efficiency of the cogeneration plant with $\mathrm{CO}_{2}$ capture is $59.7 \%$ when the SNG to power output ratio is 2.82 [13]. In this cogeneration plant, around $66 \%$ carbon is captured, and the $\mathrm{CO}_{2}$ emission and capture rates are $7.13 \mathrm{~g} / \mathrm{MJ}$-coal and $62.13 \mathrm{~g} / \mathrm{MJ}$-coal, respectively. Selexol process is selected for $\mathrm{CO}_{2}$ separation and $\mathrm{CO}_{2}$ product from the cogeneration plant is 2.0 bar [13].

In China, the main coal-fired power generation units in China are over $300 \mathrm{MW}$, accounting for over $70 \%$ of total coal-fired power generation units in 2011 [7, 9]. Now most newly built power plants have a size over $600 \mathrm{MW}$. 600MW and 1000MW are the typical sizes for supercritical and ultra-supercritical power plants, respectively. The efficiency of power plant is usually relevant to its size. The net efficiency ranges from $40 \%$ to $42 \%$ and $43 \%$ to $45 \%$ for a $600 \mathrm{MW}$ supercritical plant and a $1000 \mathrm{MW}$ ultra supercritical plant [7, 9]. For $\mathrm{CO}_{2}$ capture in a traditional coal fired power plant, post-combustion technology is the most used choice. There are many literatures investigating the energy penalty for $\mathrm{CO}_{2}$ capture. And typically the efficiency penalty is around 10-15 percentage points for a coal fired post-combustion plant with $90 \% \mathrm{CO}_{2}$ capture [16-18]. To get a fair comparison, the same carbon capture rate (for post-combustion, carbon capture rate is equal to $\mathrm{CO}_{2}$ capture rate as all carbon is oxidized into carbon dioxide) with the cogeneration plant is assumed. And it was reported that the efficiency penalty had an almost linear relationship with $\mathrm{CO}_{2}$ capture rate [19], and thereby the net plant efficiency will decrease by 6.6-10.0 percentage points when $66 \% \mathrm{CO}_{2}$ is captured for post-combustion plants. It is worth noting that these data have included the energy penalty to compress $\mathrm{CO}_{2}$ into $11 \mathrm{MPa}$.

For traditional single SNG production plant, its size ranges from 1 to 4 billion $\mathrm{Nm}^{3}$ per year and its efficiency ranges from $55 \%$ to $60 \%$ [9]. In our paper, a plant size around $3.5 \mathrm{Nm}^{3}$ per year is used. In such a plant, acid gases including sulfur and $\mathrm{CO}_{2}$ have been captured due to the requirement of SNG synthesis, as discussed in section 2 . In some plants sulfur and $\mathrm{CO}_{2}$ are not separated. But in most cases, $\mathrm{CO}_{2}$ will be separated from the mixture, and sulfur is recovered. The main difference between SNG plant with and without $\mathrm{CO}_{2}$ capture is the addition of $\mathrm{CO}_{2}$ compression. In a single SNG plant with $\mathrm{CO}_{2}$ capture, $\mathrm{CO}_{2}$ product is usually compressed to be a certain pressure for other uses (for example, $\mathrm{CO}_{2}$ is sold to food industry). If $\mathrm{CO}_{2}$ is not captured, high purity $\mathrm{CO}_{2}$ is typically emitted into atmosphere.

The boilers used for generating heating or industry steam have two types: coal-fired and gas-fired. The efficiency of gas-fired boiler is between $80 \%$ and $85 \%$, which is much higher than $55 \%-75 \%$ of coal-fired boilers $[7,9]$. And the gas-fired power plant has a typical size of $180 \mathrm{MW}$ and $350 \mathrm{MW}$ in China, and its power supply efficiency is from 55\% to 60\% [7, 9]. For combined heat and power (CHP) plant, its efficiency greatly depends on the ratio of steam to power output. In this paper, it is assumed that the steam and power from CHP to end user is the same as PG with CC-steam-power pathway. $\mathrm{CO}_{2}$ will be also captured from CHP plant, and then is sent to transportation and storage. The efficiency of CHP with $66 \% \mathrm{CO}_{2}$ capture (CHP with $\mathrm{CC}$ ) is calculated to be $48 \%$. The detailed technical parameters of different kinds of $\mathrm{CO}_{2}$ capture plants is listed in Table 1. 
Table 1 Technical parameters of different kinds of $\mathrm{CO}_{2}$ capture plants

\begin{tabular}{|c|c|c|c|c|c|c|}
\hline \multirow[t]{2}{*}{ Parameter } & \multirow[t]{2}{*}{ Unit } & \multirow{2}{*}{$\begin{array}{lr}P G & \text { plant } \\
\text { with } & C C \\
{[10]} & \end{array}$} & \multirow{2}{*}{$\begin{array}{l}\text { PC w/o CC [24-26] } \\
\text { Ultra/Supercritical/Averag } \\
\mathrm{e}\end{array}$} & \multicolumn{2}{|c|}{ PC with CC [16-18] } & \multirow{2}{*}{$\begin{array}{l}\text { Single } \\
\text { with } \quad C C \\
{[7-8,20-23]}\end{array}$} \\
\hline & & & & \multicolumn{2}{|c|}{ Ultra/Supercritical/ Average } & \\
\hline $\begin{array}{l}\text { Coal feed } \\
\text { type }\end{array}$ & - & Bituminous & Bituminous & \multicolumn{2}{|l|}{ Bituminous } & Bituminous \\
\hline Fuel input & MW & 728.2 & $1000 / 600 / 300$ & \multicolumn{2}{|l|}{$1000 / 600 / 300$} & 728.2 \\
\hline SNG output & MW & 321.0 & - & \multicolumn{2}{|l|}{-} & $400.5-436.9$ \\
\hline $\begin{array}{l}\text { Power } \\
\text { output }\end{array}$ & MW & $113.7^{\mathrm{a}}$ & $430-450 / 240-252 / 114.6$ & \multicolumn{2}{|c|}{$330-384 / 180-212.4 / 84.6-94.8^{b}$} & - \\
\hline $\begin{array}{l}\text { Net } \\
\text { efficiency }\end{array}$ & $\%$ & $59.7^{\mathrm{a}}$ & $43-45(44) / 40-42(41) / 38.2^{c}$ & \multicolumn{2}{|c|}{$\begin{array}{l}\text { 33-38.4(35.7)/30-35.4(32.7)/28.2-31.6(29.9) } \\
\text { b }\end{array}$} & $\begin{array}{l}55-60(57.5) \\
d\end{array}$ \\
\hline $\begin{array}{l}\mathrm{CO}_{2} \\
\text { compressio } \\
n^{e}\end{array}$ & MW & 15.1 & - & \multicolumn{2}{|l|}{$-/-/-$} & 14.5 \\
\hline $\begin{array}{l}\text { SNG to } \\
\text { power } \\
\text { output ratio }\end{array}$ & - & 2.82 & - & \multicolumn{2}{|l|}{-} & - \\
\hline $\begin{array}{l}\mathrm{CO}_{2} \\
\text { emission } \\
\text { rate }\end{array}$ & $\begin{array}{l}\mathrm{g} / \mathrm{MJ} \\
\text { coal }\end{array}$ & 7.13 & 93.98 & \multicolumn{2}{|l|}{31.85} & 1.734 \\
\hline $\begin{array}{l}\mathrm{CO}_{2} \text { capture } \\
\text { rate }\end{array}$ & $\begin{array}{l}\mathrm{g} / \mathrm{MJ} \\
\text { coal }\end{array}$ & 62.13 & - & \multicolumn{2}{|l|}{62.13} & 59.63 \\
\hline$S N G L H V$ & $\mathrm{MJ} / \mathrm{kg}$ & 43.61 & - & & & - \\
\hline Parameter & Unit & $\begin{array}{l}\text { NGCC [7, } \\
\text { 9] }\end{array}$ & NG steam boiler [7, 9] & Coal steam boiler $[7,9]$ & CHP & $\begin{array}{l}\text { CHP with } \\
\text { CC }\end{array}$ \\
\hline Fuel input & MW & 750 & 400 & 400 & 750 & 750 \\
\hline $\begin{array}{l}\text { Steam } \\
\text { output }\end{array}$ & MW & - & $320-340$ & $220-300$ & 428.2 & 256.7 \\
\hline $\begin{array}{l}\text { Power } \\
\text { output }\end{array}$ & MW & $412.5-450$ & - & - & 149.3 & 103.3 \\
\hline $\begin{array}{l}\text { Net } \\
\text { efficiency }\end{array}$ & $\%$ & $\begin{array}{l}55-60(57.5 \\
)\end{array}$ & $80-85(82.5)$ & $55-75(65)$ & 77 & $48^{\mathrm{b}}$ \\
\hline $\begin{array}{l}\mathrm{CO}_{2} \\
\text { emission } \\
\text { rate }\end{array}$ & $\begin{array}{l}\text { g/MJ-fue } \\
1\end{array}$ & 56.1 & 56.1 & 93.98 & 93.98 & 31.85 \\
\hline $\begin{array}{l}\mathrm{CO}_{2} \text { capture } \\
\text { rate }\end{array}$ & $\begin{array}{l}\text { g/MJ-fue } \\
1\end{array}$ & - & - & - & - & 62.13 \\
\hline
\end{tabular}

Note: Before transportation, all $\mathrm{CO}_{2}$ products is compressed to $11 \mathrm{MPa}$.

${ }^{a} \mathrm{CO}_{2}$ product is $2.0 \mathrm{bar} .{ }^{b} \mathrm{CO}_{2}$ is compressed to $11 \mathrm{MPa} .{ }^{c}$ data in the brackets represent the medium values. ${ }^{d} \mathrm{CO}_{2}$ product is 2 bar. ${ }^{e}$ $\mathrm{CO}_{2}$ is compressed to $11 \mathrm{MPa}$.

4.2 Coal mining, transportation, power transmission \& distribution

The basic energy consumption and GHG emission data for coal mining, transportation have been discussed in our previous paper [9]. We do not discuss the selection process of these data, and just present them here. According to the national statistics data published in 2012 [27], the energy consumption for 
mining and washing one ton coal was $24.1 \mathrm{kWh}$ power, $71.7 \mathrm{~kg}$ raw coal, $0.21 \mathrm{~m}^{3}$ natural gas and $0.64 \mathrm{~kg}$ oil. The fugitive GHG emissions during coal mining and washing are also considered in this paper, which are reported to be 7.0-10.0 cubic meters methane and 6 cubic meters $\mathrm{CO}_{2}$ for each ton of coal mined [28-30].

It is assumed that all power generation, single SNG product or cogeneration with $\mathrm{CO}_{2}$ capture plants are built near the coal mines. Coal is transported to these plants by diesel truck within the range of $50 \mathrm{~km}$ [7]. It was assumed that transporting coal by truck consumed $1480 \mathrm{~kJ} /(\mathrm{t} \mathrm{km})$ diesel oil [7, 9]. Long distance coal transportation is assumed for coal steam pathway. A combination of railway, waterway and highway [7] is the most common way for long distance coal transportation, and averagely the distance is $1500 \mathrm{~km}$ for waterway, $640 \mathrm{~km}$ for railway, and $500 \mathrm{~km}$ for highway [7]. The energy consumption is $203 \mathrm{~kJ} /(\mathrm{t} \mathrm{km})$ diesel oil and $78 \mathrm{~kJ} /(\mathrm{t} \mathrm{km})$ electricity for railway coal transportation, and is $257 \mathrm{~kJ} /(\mathrm{t} \mathrm{km})$ fuel oil for waterway transportation $[7,9]$.

The main energy consumption is the power loss during electricity transmission, and it was reported to be $6.3 \%$ in 2015 [31].

\section{$4.3 \mathrm{CO}_{2}$ compression, transportation \& storage}

After the capture process, the concentrated $\mathrm{CO}_{2}$ will be compressed to supercritical state for transportation. Pipeline is treated as one of the cheapest and most used methods for large scale and long distance $\mathrm{CO}_{2}$ transportation. In consideration of the pipeline distance and pressure drop, $\mathrm{CO}_{2}$ is assumed to be compressed to 11 $\mathrm{MPa}$. The electricity requirement for $\mathrm{CO}_{2}$ compression is calculated by the following Eqs. (4) and (5), which is derived from literature [32-33].

$$
\begin{aligned}
& W=\frac{Z R T_{1}}{M} \frac{N_{\gamma}}{\gamma-1}\left[\left(\frac{p_{2}}{p_{1}}\right)^{\gamma-1 / N_{\gamma}}-1\right] \\
& E=\frac{W}{3600 \eta_{i s} \eta_{m}}
\end{aligned}
$$

where $\mathrm{W}$ is the ideal specific work, $\mathrm{kJ} / \mathrm{kg}-\mathrm{CO}_{2} ; \mathrm{Z}$, compressibility factor (0.9942); R, gas constant (8.3145 $\mathrm{J} /($ mole $\mathrm{K})$ ); $\mathrm{T}_{1}$, suction temperature $(313.15 \mathrm{~K}) ; \mathrm{g}$, specific heat ratio $\left(\mathrm{C}_{\mathrm{p}} / \mathrm{C}_{\mathrm{v}}\right)(1.293759) ; \mathrm{M}$, molar mass (44.01 $\mathrm{g} / \mathrm{mole}$ ); $\mathrm{p}_{1}$, suction pressure (MPa) (injection=10.7); $\mathrm{p}_{2}$, discharge pressure (MPa) (transport=11, injection=15); $\mathrm{N}$, number of compressor stages (transport=4, injection=2); $\eta_{\mathrm{is}}$, isentropic efficiency $(80 \%) ; \eta_{\mathrm{m}}$, mechanical efficiency (99\%) [32-33].

The fugitive $\mathrm{CO}_{2}$ emissions during compression and pipeline transportation are also considered in this paper. With the use of the methodology developed by the IPCC [34], the fugitive $\mathrm{CO}_{2}$ emissions is 7.0-116.1 t $\mathrm{CO}_{2} / \mathrm{MW} / \mathrm{yr}$ from compressor and 0.2-23.2 $\mathrm{t} / \mathrm{km} /$ year from pipeline transportation. As most $\mathrm{CO}_{2}$ capture plant will be matched to its nearby storage site, $50 \mathrm{~km}$ pipeline is assumed in this paper.

$3.6 \mathrm{CO}_{2}$ injection and storage

There are several kinds of $\mathrm{CO}_{2}$ storage including saline aquifers, enhance oil recovery (EOR), enhance coal bed methane (ECBM), and enhance gas recovery (EGR) etc. Saline aquifers are thought to have the hugest capacity for $\mathrm{CO}_{2}$ storage, so in this paper $\mathrm{CO}_{2}$ storage in aquifers is considered. The energy consumption for injection and storage is the recompression of $\mathrm{CO}_{2}$ to overcome reservoir pressure [32]. The recompression pressure is decided by the depth of the reservoir, and in this paper it is assumed to be $15 \mathrm{MPa}$, a typically value for geological storage in some existing operational projects [32]. The pressure drop over a 50km pipeline is assumed to be $0.3 \mathrm{MPa}$ [32], and therefore the energy requirement for $\mathrm{CO}_{2}$ injection and storage is recompression work from 10.7 MPa to $15 \mathrm{MPa}$. Further, it is assumed that leakage of the injected $\mathrm{CO}_{2}$ to the atmosphere will not occur or is limited to insignificant amounts [32]. 


\section{Results and discussions}

\subsection{Life cycle energy use and GHG emissions for power generation pathway}

The life cycle energy use of the PG with CC and its competitive pathways are presented in Figure 4. When SNG is produced in a single product plant without $\mathrm{CO}_{2}$ capture, its life cycle energy use was reported to be higher than supercritical and USC power pathways due to high energy consumption in SNG production [9]. While when SNG is produced in a single product plant with $\mathrm{CO}_{2}$ capture, its life cycle energy use is averagely around 5\% lower than that of supercritical coal power with CC and even can be comparable with USC with CC pathway. Such low energy use is mainly due to low energy penalty for $\mathrm{CO}_{2}$ capture in a SNG production plant and high energy penalties for $\mathrm{CO}_{2}$ capture in post-combustion coal power plants. Typically, in a SNG product, $\mathrm{CO}_{2}$ must be removed to get a fresh syngas with proper $\mathrm{H}_{2} / \mathrm{CO}$ mole ratio to satisfy the subsequent chemical synthesis reactions. Only energy for $\mathrm{CO}_{2}$ purification and compression are needed if $\mathrm{CO}_{2}$ capture is applied. But in coal power pathways, typically 10-15 efficiency penalties are needed if $90 \% \mathrm{CO}_{2}$ is captured. It was previously investigated in our work that when SNG is produced in a cogeneration plant without $\mathrm{CO}_{2}$ capture, its life cycle energy use is typically lower than supercritical coal power, but is still $1.6 \%$ higher than USC coal power pathway due to the efficiency improvement of cogeneration [9]. With $\mathrm{CO}_{2}$ capture, the life cycle energy use of PG with CC is 10\%-19\% lower than that of USC coal power with $\mathrm{CC}$ due to the obvious higher $\mathrm{CO}_{2}$ concentration before separation and the consequent much lower energy penalties for $\mathrm{CO}_{2}$ capture.

Correspondingly, the types of energy consumption for producing $1 \mathrm{MJ}$ electricity (excluding electricity output) and GHG emissions of different pathways are presented in Figs. 5 and 6, respectively. Coal energy consumption dominates for all pathways and natural gas/SNG is also consumed in a NGCC power plant for PG with CC and single SNG-power with CC pathways. Electricity consumption is mainly caused during electricity transmission, $\mathrm{CO}_{2}$ compression, transportation \& injection. The life cycle GHG emissions of PG with CC pathway range from 135 to $150 \mathrm{gCO}_{2}$ eq. /MJ, which are obviously lower than those of all coal power pathways including USC units (10\%-17\% lower than USC coal power with CC pathway). Less $\mathrm{CO}_{2}$ is emitted in cogeneration and power generation plants due to high efficiency of $\mathrm{SNG}$ and power cogeneration and low energy penalty for $\mathrm{CO}_{2}$ capture. More energy is needed to compress $\mathrm{CO}_{2}$ for transportation in PG plant with $\mathrm{CC}$, and therefore more emissions are expected. In PG with CC pathway, part of energy is transmitted in the form of SNG through pipelines, while long distance electricity transmission is needed in coal power pathways. Thus, more GHG emissions are expected in SNG transmission but less are expected in electricity transmission in PG with CC pathway.

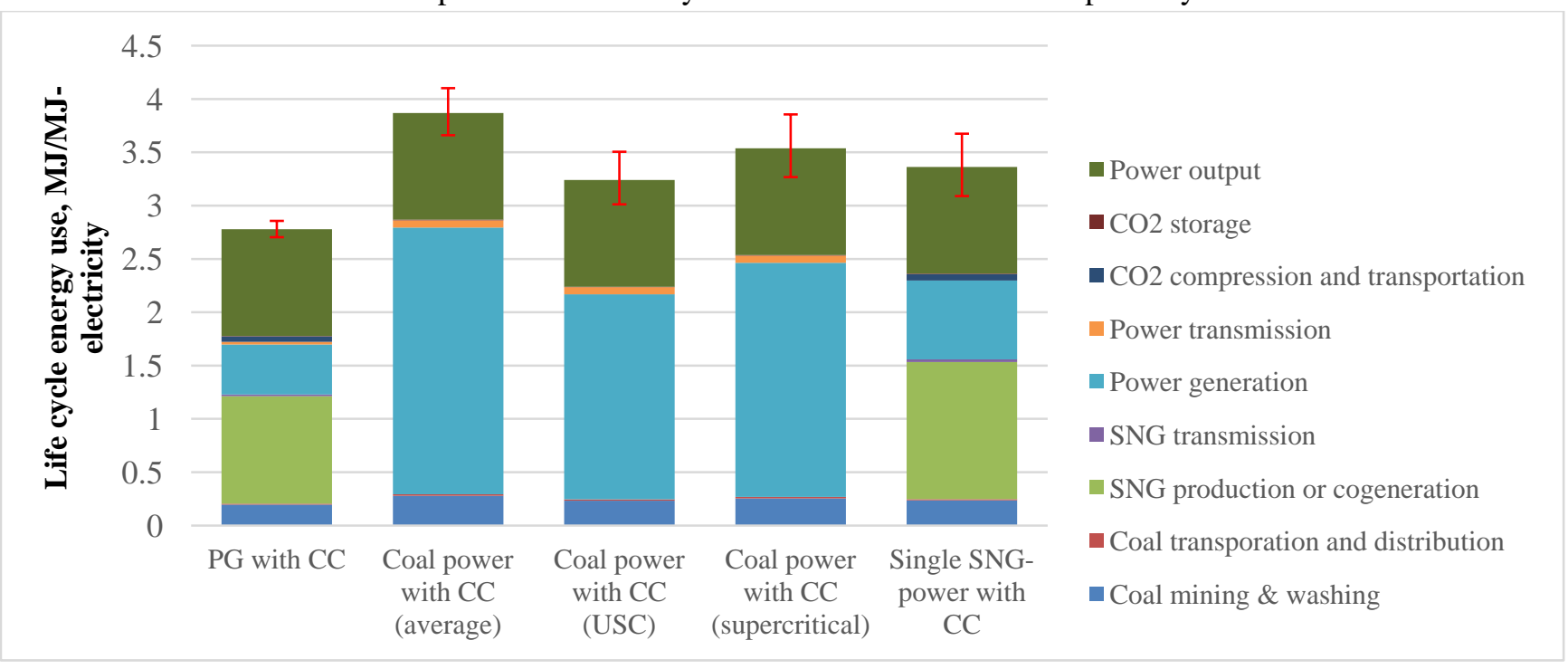

Figure 4 Life cycle energy use of power generation pathway 


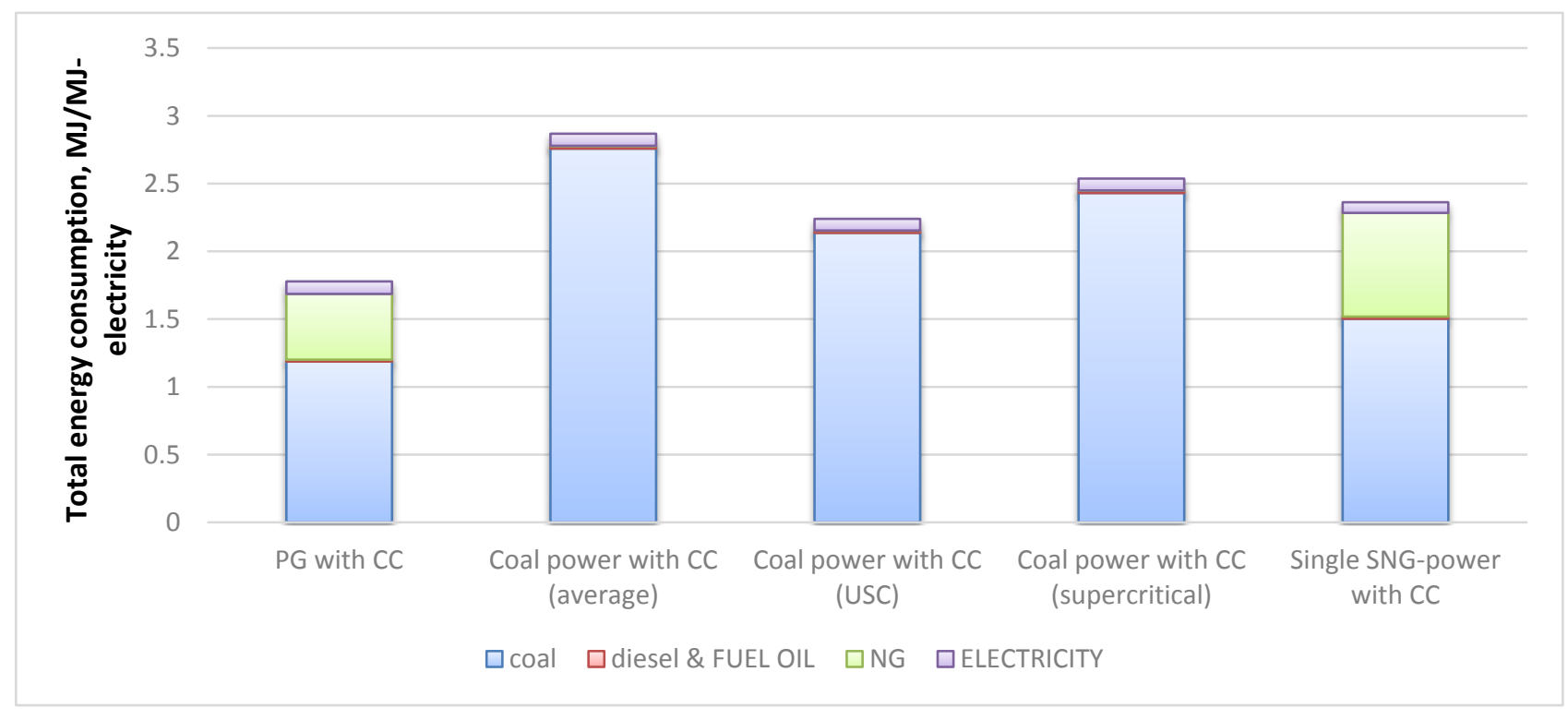

Figure 5 Types of energy consumption for producing 1MJ electricity (excluding electricity output)

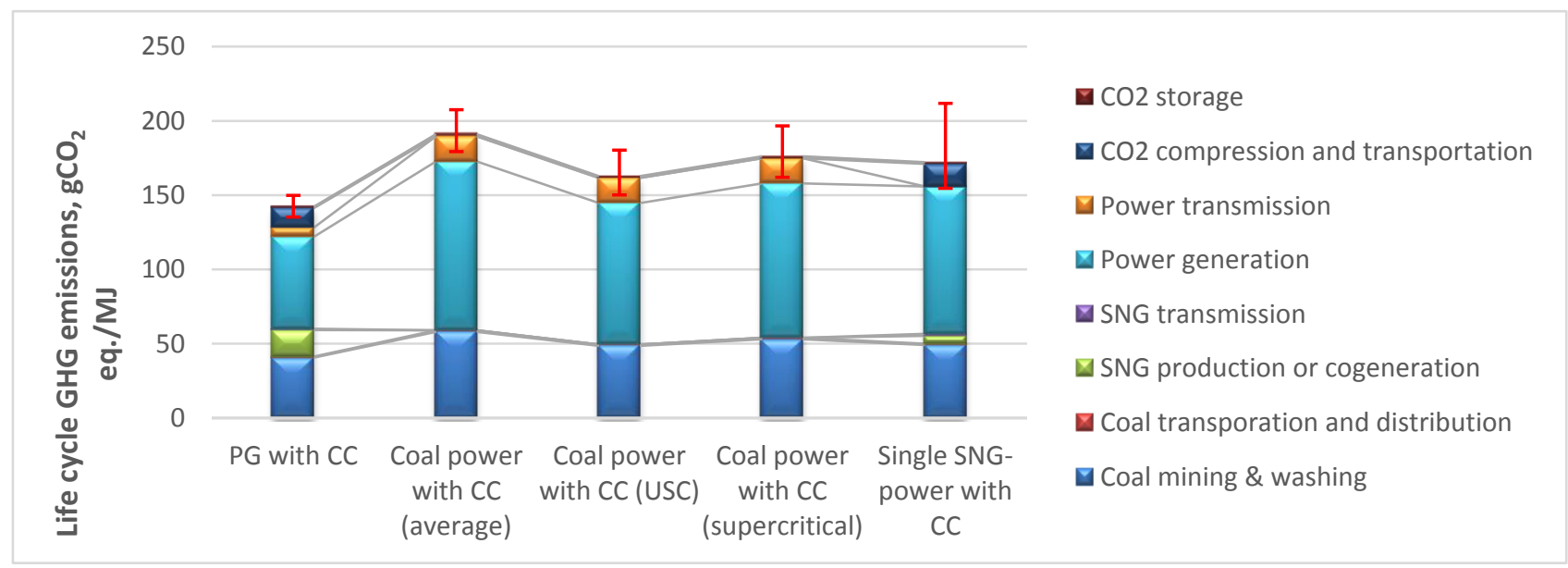

Figure 6 Life cycle GHG emissions of power generation pathway

5.2 Life cycle energy use and GHG emissions for combined steam and power cogeneration pathway

To provide $0.713 \mathrm{MJ}$ steam and $0.287 \mathrm{MJ}$ electricity ( $1 \mathrm{MJ}$ in total) to the end users, the life cycle energy use is 2.13-2.23MJ for PG with CC-steam-power pathway, 2.13-2.68 MJ for combined coal power with CC (average) and coal-steam pathway, 2.02-2.61 MJ for combined supercritical with CC and coal-steam pathway, and 1.95-2.50 MJ for combined USC with CC and coal-steam pathway (Fig. 7). It was reported in our previous work that the life cycle energy use of PG-steam-power without $\mathrm{CO}_{2}$ capture pathway is 1.95-2.05 MJ [9] and can be comparable with those of combined coal-steam and coal-power without $\mathrm{CO}_{2}$ capture pathways due to a higher efficiency of a SNG fired boiler than a coal fired boiler and the cogeneration benefit. However, when $\mathrm{CO}_{2}$ capture is applied, the life cycle energy use of PG with CC-steam-power pathway is around 9\% higher than PG-steam-power without $\mathrm{CO}_{2}$ capture pathway, and is typically lower than all combined coal power with $\mathrm{CC}$ and coal-steam pathways due to the low energy requirement for $\mathrm{CO}_{2}$ capture in a PG plant. Compared with $\mathrm{CHP}$ with $\mathrm{CC}$, the life cycle energy use of PG pathway is 7\% 11\% lower due to its advantages in low energy $\mathrm{CO}_{2}$ capture.

The life cycle GHG emissions of PG with CC-steam-power pathway have a range of 106.6-117.0 $\mathrm{gCO}_{2}$ eq./MJ with an average value 111.4, which are much lower than combined coal-power with $\mathrm{CC}$ and 
coal-steam pathways. It can be seen from Fig. 8 that the main differences of GHG emissions come from fuel combustion boilers. In PG with CC-steam-power pathway, SNG fired boiler is used to generate steam and its efficiency (average 83.5\%) is much higher than a coal fired boiler (average 65\% in China), and the emission factor of SNG is also much lower than coal. Due to the both factors, the emissions from fuel combustion boilers are much lower in PG with CC-steam-power pathway. And for each pathway, those from cogeneration and fuel combustion in boiler contribute to the largest part of the total GHG emissions. Compared with CHP with CC pathway, the GHG emissions of PG with CC-steam-power pathway are 8.5\% 17\% lower due to its lower energy use.

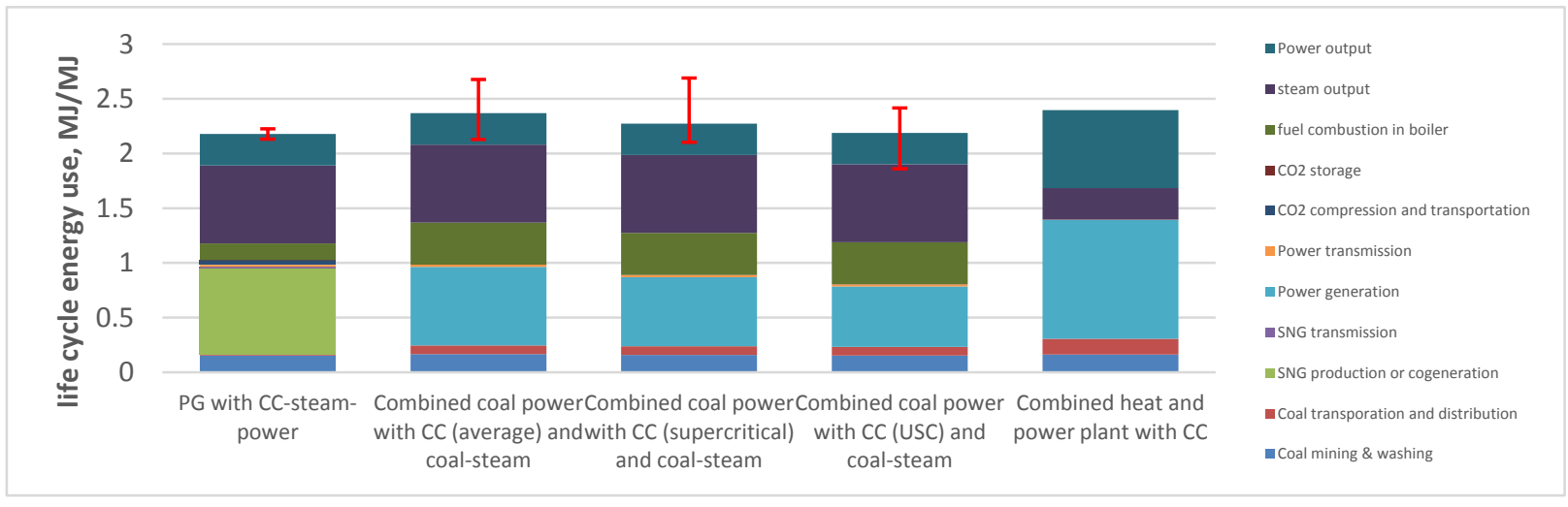

Figure 7 Life cycle energy use of combined steam and power cogeneration pathway

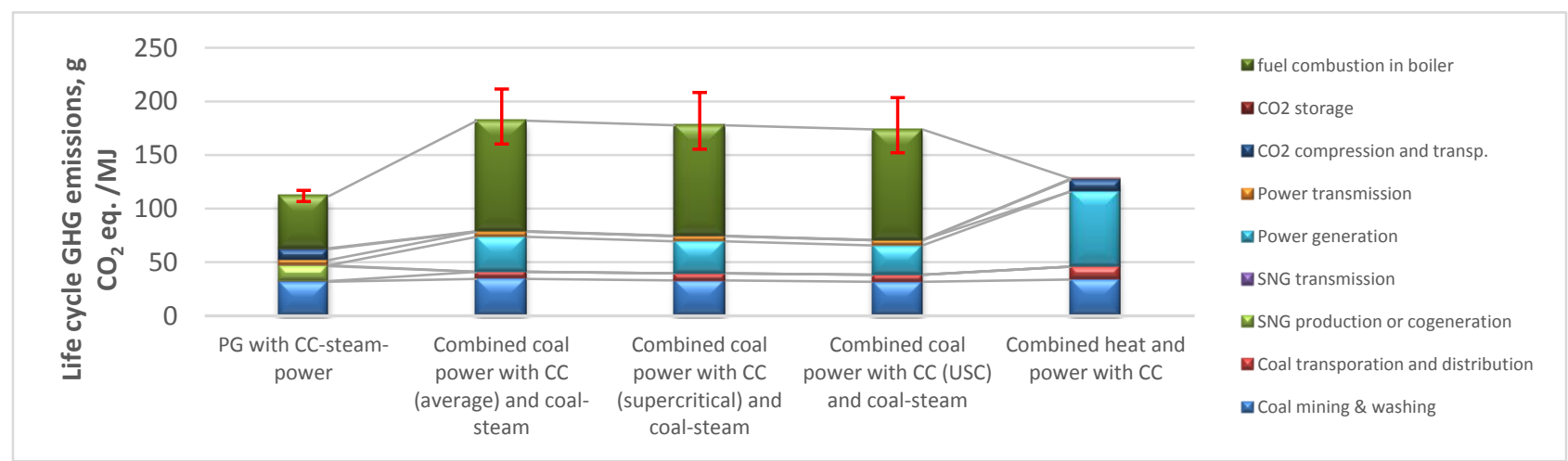

Figure 8 Life cycle GHG emissions of combined steam and power cogeneration pathway

5.3 Life cycle energy use and GHG emissions for combined vehicle operation and power cogeneration pathway

SNG or NG is also considered a very import fuel for cars. For PG with CC-SNGV pathway, the electricity and SNG generated from PG with CC plant is transmitted to urban area, and then SNG is used to drive cars. The reference base for PG with CC-SNGV pathway is $0.249 \mathrm{MJ}$ electricity and 0.751 MJ SNG sent to the end users, which sum up to be $1 \mathrm{MJ}$. It is assumed that all other pathways produce the same electricity to the end users and the power from the alternative pathways can drive the same car for the same distance with PG with CC-SNGV pathway. As shown in Fig. 9, the SNG driven car consumes much higher energy (around $2.77 \mathrm{MJ} / \mathrm{km}$ ) than the electricity driven car $(0.719 \mathrm{MJ} / \mathrm{km})$ for the same traveling distance, resulting in the life cycle energy use of PG with CC-SNGV pathway is $1.89 \mathrm{MJ} /(0.249 \mathrm{MJ}$ electricity $+0.271 \mathrm{~km}$ car traveling) and is much higher than all combined coal power with CC-BEV and coal power with CC pathways.

Correspondingly, the life cycle GHG emissions of PG-SNGV-power pathway range from 95 to $101 \mathrm{gCO}_{2}$ eq./ (0.249 MJ electricity $+0.271 \mathrm{~km}$ car traveling) and are also higher than all other competitive alternatives (Fig. 10). Vehicle operation is the largest emitter and followed by SNG cogeneration for PG with CC-SNGV pathway. For other coal alternatives, power generation are the main GHG emission sources. 


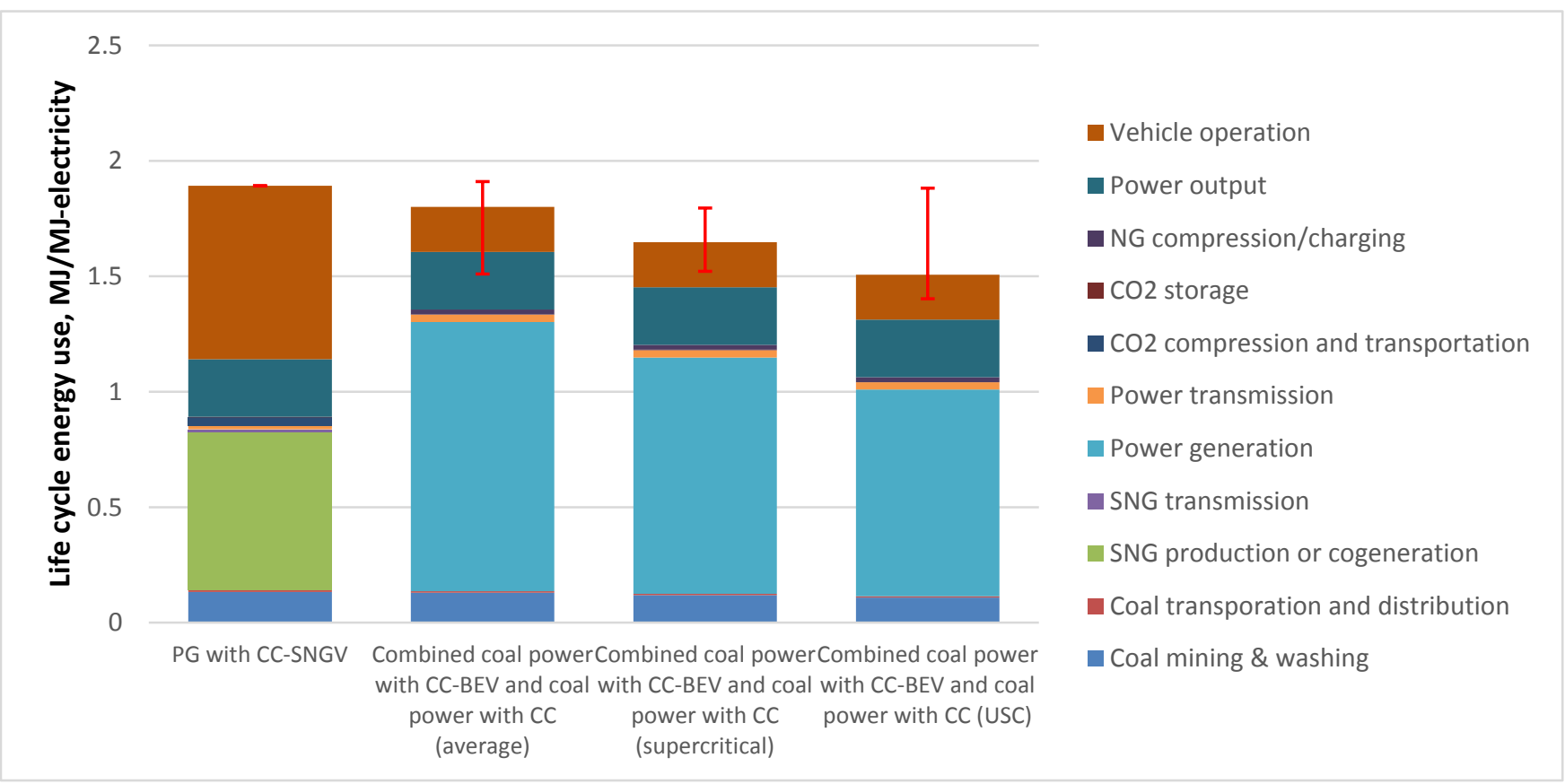

Figure 9 Life cycle energy use of combined vehicle operation and power cogeneration pathway

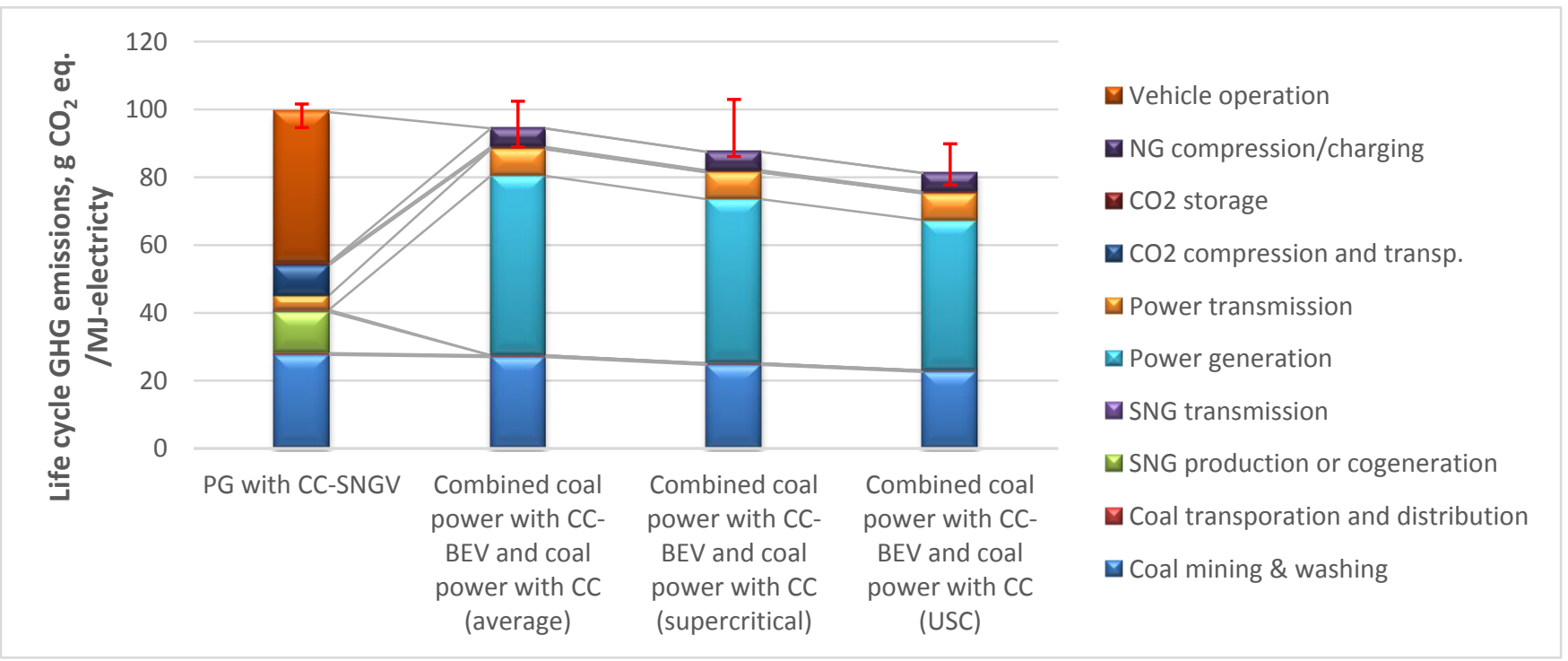

Figure 10 Life cycle GHG emissions of combined vehicle operation and power cogeneration pathway 5.4 Life cycle energy use and GHG emissions for pure vehicle operation pathway

It is different from PG with CC-SNGV pathway that the SNG produced from PG with CC plant is sent to generate electricity in NGCC power plant first and then the electricity is used to drive passenger car in the PG with CC-BEV pathway. The reference base is $1 \mathrm{~km}$ car traveling distance. As shown in Fig. 11, the life cycle energy use of 2.16-2.19MJ/km, which is much lower than single SNG with CC-BEV (2.47-2.94 MJ/km) or single SNG with CC-SNGV (5.14-5.60 MJ/km) pathways. Due to the much higher efficiency of the PG plant with CC than coal power plant with $\mathrm{CC}$, the life cycle energy use of PG with CC-BEV pathway are 10\%-23\% lower than USC coal power with CC-BEV pathways.

The average life cycle GHG emissions of PG with CC-BEV pathway is $133.8 \mathrm{gCO}_{2}$ eq. $/ \mathrm{km}$ with a range of 128.3-140.0 $\mathrm{gCO}_{2} \mathrm{eq} . / \mathrm{km}$, which are lower than the average level of $173.0 \mathrm{gCO}_{2} \mathrm{eq} . / \mathrm{km}$ for coal-BEV (average), $161.0 \mathrm{gCO}_{2}$ eq./km for supercritical coal-BEV, and $150.3 \mathrm{gCO}_{2}$ eq./km for USC coal power with CC-BEV pathways (Fig. 12). For single SNG with CC-BEV pathway, its life cycle GHG emissions (143.7-174.1 $\mathrm{gCO}_{2}$ eq. $/ \mathrm{km}$ ) are comparable to USC coal power with $\mathrm{CC}-\mathrm{BEV}$ pathway. For single SNG with CC-SNGV pathway, its life cycle GHG emissions are 263.4-299.8 $\mathrm{gCO}_{2}$ eq./km that are obviously higher than all coal power 
with CC-BEV pathways due to large energy consumption both in SNG production process and in vehicle operation process.

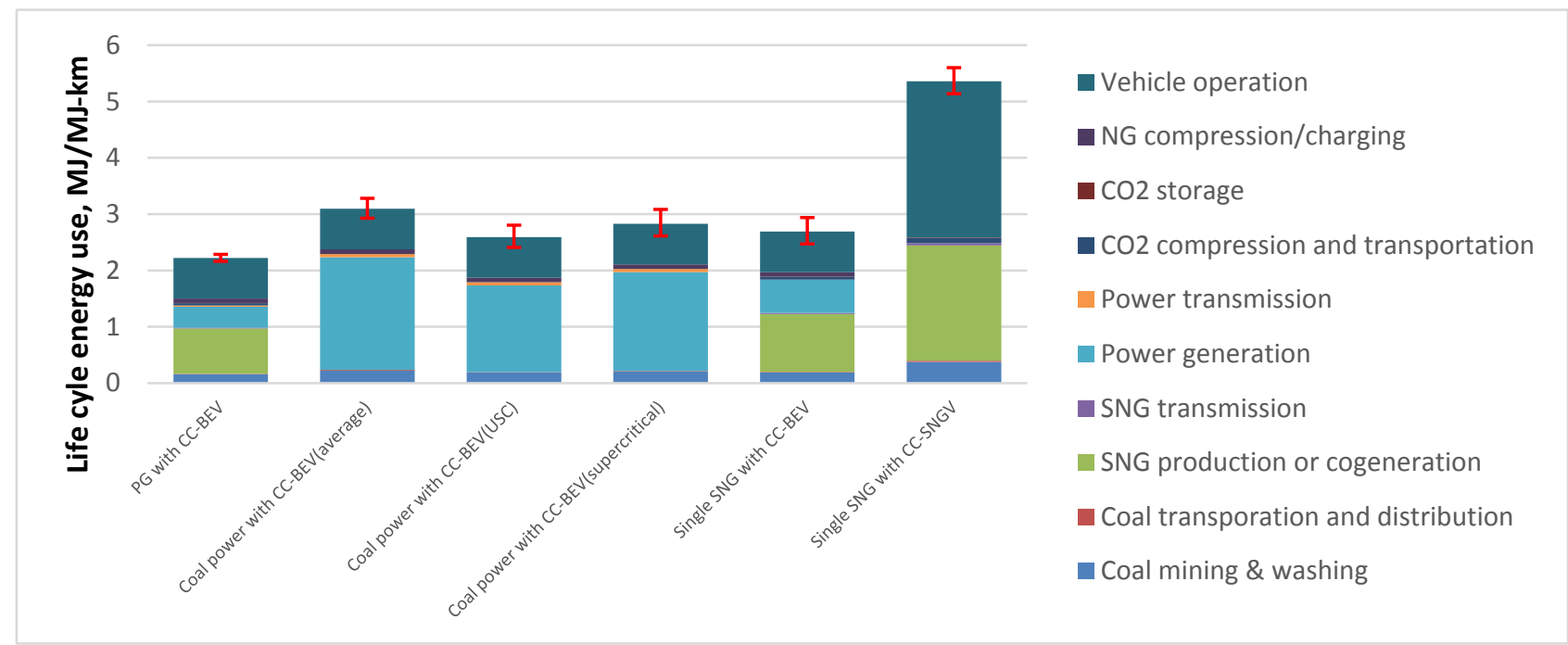

Figure 11 Life cycle energy use of pure vehicle operation pathway

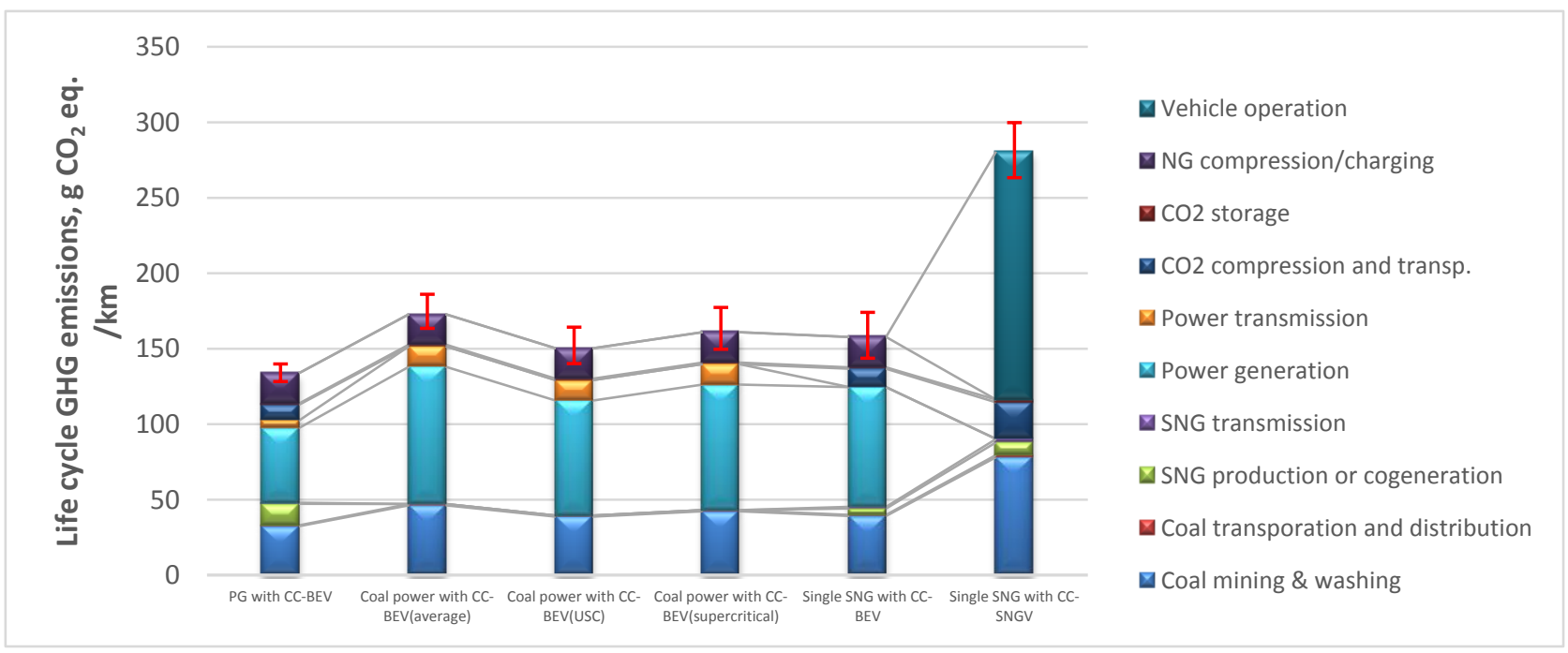

Figure 12 Life cycle GHG emissions of pure vehicle operation pathway

\section{Conclusions}

Clean, efficient, and decarbonization utilization of coal is an important issue for countries abundant with coal resources. Coal to SNG, as a type of clean coal technology, is under demonstration in China, but controversy arises around its environmental problems. If not integrated with $\mathrm{CO}_{2}$ capture, production of SNG from traditional single product plant can only be comparable with the average level of coal power pathways in terms of life cycle energy use and GHG emissions. Due to much lower energy penalty for $\mathrm{CO}_{2}$ capture, coal to SNG combined with CCS shows around 5\% lower life cycle energy use than that of supercritical coal power with CC and even can be comparable to USC coal power with CC pathway.

The cogeneration technology with $\mathrm{CO}_{2}$ capture shows obvious life cycle energy use and GHG emission advantages over its competitive pathways. When SNG is used to generate power, the life cycle energy use of cogeneration plant with CC is $10 \%-19 \%$ lower than that of USC coal power with CC due to system integration, the obvious higher $\mathrm{CO}_{2}$ concentration before separation and the consequent much lower energy penalties for $\mathrm{CO}_{2}$ capture. The life cycle GHG emissions of cogeneration with CC pathway range from 135 to $150 \mathrm{gCO}_{2}$ eq./MJ, 
which are obviously lower than those of all coal power pathways including USC units (10\%-17\% lower than USC with CC). If SNG is used to generate steam, the life cycle energy use and GHG emissions of PG with CC pathway can be lower than other combined coal power and coal steam pathways including CHP with CC. However, when SNG is directly used to driven a car, the PG with CC pathway does not show advantages over combined coal power and coal power-BEV pathways. Instead, if SNG is used for power generation first and then the generated power is used to driven a BEV car, the PG with CC pathway has obvious lower life cycle energy use and GHG emissions compared to coal power-BEV pathways.

Facing the challenges of coal dominated energy structure, energy security and increasing oil and gas dependency, and GHG emissions reduction, China needs to develop its own way to efficient and environmentally friendly coal conversion, and cogeneration of SNG and power with $\mathrm{CO}_{2}$ capture is attractive and provides such a solution. The results presented in this paper answer the question that whether coal to SNG is attractive regarding two important issues: life cycle energy use and GHG emissions, and give more scientific proof to start a real demonstration of polygeneration plant with $\mathrm{CO}_{2}$ capture. Also, the results can be used for further modelling the PG technology to predict its role in energy saving and GHG emissions at a national level.

\section{Acknowledgements}

This work is supported by the National Science Foundation of China through the grant No. 51306185 and Youth Innovation Promotion Association CAS.

\section{References}

[1] Li S, Ji X, Zhang X, Gao L, Jin H. Coal to SNG: Technical progress, modeling and system optimization through exergy analysis. Applied Energy 2014; 136: 98-109.

[2] Calderón A. J., Agnolucci P., Papageorgiou L. G. An optimisation framework for the strategic design of synthetic natural gas (BioSNG) supply chains. Applied Energy, 2017, 187: 929-955.

[3] Zhang J., Liang Y., Harpalani S. Optimization of methane production from bituminous coal through biogasification. Applied Energy, 2016, 183: 31-42.

[4] Alamia A., Magnusson I., Johnsson F., Thunman H. Well-to-wheel analysis of bio-methane via gasification, in heavy duty engines within the transport sector of the European Union. Applied Energy, 2016, 170: 445-454.

[5] National Bureau of Statistics of China (NBS). China Statistical Yearbook. China Statistics Press, Beijing, 2009-2013.

[6] Li S, Gao L. Greenhouse gas emissions from synthetic natural gas. Nature Climate Change 2016; 6: 220-221.

[7] Ding Y, Han W, Chai Q, Yang S, Shen W. Coal-based synthetic natural gas (SNG): A solution to China's energy security and $\mathrm{CO}_{2}$ reduction? Energy Policy 2014; 55: 445-453.

[8] Jaramillo P, Griffin W. M, Matthews H. S. Comparative Life-Cycle Air Emissions of Coal, Domestic Natural Gas, LNG, and SNG for Electricity Generation. Environmental Science and Technology 2007; 41: 6290-6296.

[9] Li S, Gao L, Jin H. Life cycle energy use and GHG emission assessment of coal-based SNG and power cogeneration technology in China. Energy Conversion and Management 2016; 112: 91-100.

[10] Li S, Jin H, Gao L. Cogeneration of substitute natural gas and power from coal by moderate recycle of the chemical unconverted gas. Energy 2013; 15: 667-658.

[11] Li S, Jin H, Gao L, Zhang X. Exergy analysis and the energy saving mechanism for coal to synthetic/substitute natural gas and power cogeneration system without and with $\mathrm{CO}_{2}$ capture. Applied Energy 2014; 130: 561-552.

[12] Li S, Jin H, Gao L, Zhang X, Ji X. Techno-economic performance and cost reduction potential for the substitute/synthetic natural gas and power cogeneration plant with $\mathrm{CO}_{2}$ capture. Energy Conversion and Management 2014; 85: 887-875. 
[13] Li S, Jin H, Gao L. Coal-based Cogeneration System for Synthetic/Substitute Natural Gas and Power With $\mathrm{CO}_{2}$ Capture After Methanation: Coupling Between Chemical and Power Production. Journal of Engineering Gas Turbines and Power 2014; 136 (9): 091501.

[14] IPCC. Draft 2006 IPCC Guidelines for National Greenhouse Gas Inventories-Available at: https://www.ipcc.ch/meetings/session25/doc4a4b/vol2.pdf [accessed 07.25.2016].

[15] IPCC. Climate Change 2007: The Physical Science Basis. Contribution of Working Group I to the Fourth Assessment Report of the Intergovernmental Panel on Climate Change. Cambridge University Press, Cambridge, 2007, pp. 212.

[16] IPCC. IPCC Special Report on Carbon Dioxide Capture and Storage. Cambridge University Press, New York, USA, 2005.

[17] IEA. Cost and Performance of Carbon Dioxide Capture from Power Generation. Available at: http://www.iea.org/publications/freepublications/publication/costperf_ccs_powergen.pdf [accessed 07.25.2016].

[18] Damen K, Troost M, Faaij A, Turkenburg W. A comparison of electricity and hydrogen production systems with $\mathrm{CO}_{2}$ capture and storage. Part A: Review and selection of promising conversion and capture technologies. Progress in Energy and Combustion Science 2006; 32: 215-246.

[19] Li S, Jin H, Gao L, Mumford K. A., Kathryn S., Stevens G. Energy and Exergy Analyses of an Integrated Gasification Combined Cycle Power Plant with $\mathrm{CO}_{2}$ Capture Using Hot Potassium Carbonate Solvent. Environmental Science and Technology 2014; 48 (24):14814-14821.

[20] Department of Energy, USA (DOE). Practical experience gained during the first twenty years of operation of the great plains gasification plant and implications for future projects. Technical report, dakota gasification company prepared for US Department of Energy-Office of Fossil Energy, USA, 2006.

[21] Department of Energy, USA (DOE). Cost and performance baseline for fossil energy plants volume 2: coal to synthetic natural gas and ammonia. July 5, 2011.

[22] Liu Z, Gong H, Yu L. SNG development in China. Coal Chemical Industry 2009; 141 (2): 1-5.

[23] Liu Q, Xing T. A brief analysis of process and its economies for coal-based synthetic natural gas. Chemical Engineering Design 2010; 20 (3): 25-27.

[24] China Electricity Council (CEC). Annual Statistics of China Power Industry 2013. Available at: http://www.cec.org.cn/guihuayutongji/gongxufenxi/dianligongxufenxi/2014-02-25/117272.html_ [accessed 07.25.2016].

[25] Li X. Progresses in USC Thermal Power Generation Technology and Domestic Construction. Electric Power Construction 2007; 28(4): 60-66.

[26] Yan W. Review on Supercritical Steam Power Generating Technology. Electric Power Science and Engineering 2014; 30(1): 1-7.

[27] National Bureau of Statistics of China (NBS). China Statistical Yearbook. China Statistics Press, Beijing, 2012.

[28] Zheng S. Coal bed methane emission inventory in China. China Coal 2002; 28 (5): 37-40.

[29] Ma Z, Pan Z, He H. Greenhouse gas emission factor for coal power chain in China and the comparison with nuclear power chain. Chinese Journal of Nuclear Science and Engineering 1999; 19 (3): 268-274.

[30] Chinese Coal Research Institute (CCRI). Report to NDRC on Energy Efficiency, Emissions and Cost of Coal Mining and Washing. Beijing, May 6, 2006.

[31] National Development and Reform Commission (NDRC) People's Republic of China. Energy development "second five year plan". Available at: http://www.gov.cn/zwgk/2013-01/23/content_2318554.htm [accessed 07.25.2016].

[32] Koornneef J, van Keulen T, Faaij A, Turkenburg W. Life cycle assessment of a pulverized coal power plant with post-combustion capture, transport and storage of $\mathrm{CO}_{2}$. International Journal of Greenhouse Gas Control 
2008; 2: 448-467.

[33] Damen K. Reforming fossil fuels use-the merits, costs and risks of carbon capture and storage. PhD thesis.

Science, Technology and Society, Utrecht University, Utrecht, 2007.

[34] IPCC. Chapter 4: fugitive emissions, in: 2006 IPCC Guidelines for National Greenhouse Gas Inventories, vol.

2, Energy. IGES, Japan, Prepared by the National Greenhouse Gas Inventories Programme, 2006. 